Nota

\title{
CULTIVO IN VITRODE ÁPICES CAULINARES DE ABACAXIZEIRO PARA LIMPEZA CLONAL EM RELAÇÃO À FUSARIOSE
}

\author{
Cynthia Cavalcanti Albuquerque ${ }^{1 *}$; Terezinha Rangel Camara²; Maria Menezes ${ }^{3}$; Lilia Willadino4; \\ Isabelle Meunier ${ }^{5}$; Cláudia Ulisses ${ }^{6}$ \\ ${ }_{2}^{1}$ Depto. de Morfologia e Fisiologia Animal - UFRPE, Rua Dom Manoel de Medeiros s/n. - CEP: 52171-900 - Recife, PE. \\ ${ }^{2}$ Depto. de Química - UFRPE. \\ ${ }_{4}^{3}$ Depto. de Agronomia - UFRPE. \\ ${ }^{4}$ Depto. de Biologia - UFRPE. \\ ${ }^{5}$ Depto. de Ciência Florestal - UFRPE. \\ ${ }^{6}$ VerdeVitro - Biotecnologia Vegetal. \\ *Autor correspondente <vvitro@nlink.com.br>
}

RESUMO: O presente trabalho teve como objetivo adequar um meio nutritivo ao cultivo de ápices caulinares de abacaxizeiro, cv. Pérola, visando a limpeza clonal de plantas infectadas por Fusarium subglutinans, agente causal da fusariose. Inicialmente, ápices de mudas sadias, tipo coroa, foram retirados sob condições assépticas

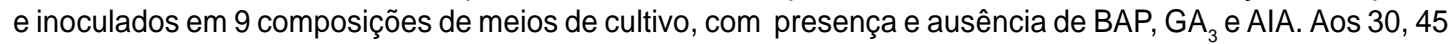
e 60 dias após a inoculação, observou-se o grau de necrose dos explantes. Nos meios selecionados inocularamse ápices caulinares retirados de mudas contaminadas por $F$. subglutinans, a fim de verificar a viabilidade da limpeza clonal. Os resultados mostraram que houve influência do meio de cultivo na regeneração de plantas e a viabilidade da limpeza clonal de mudas infectadas, também foi constatada uma vez que $100 \%$ das plantas regeneradas estavam livres do patógeno.

Palavras-chave: Ananas comosus, abacaxi, meio nutritivo, ápice caulinar

\section{SHOOT TIP IN VITRO CULTURE OF PINEAPPLE FOR FUSARIUM ELIMINATION}

\begin{abstract}
The object of this study was to find a nutricional means for the cultivation of the shoot tips of Perola pineapples, in order to free them of infections caused by Fusarium subglutinas. The first step was to remove healthy shoot tips from healthy crowns under aseptic conditions and inoculate nine different cultivation media with or whithout traces of BAP, GA3 and AIA. The levels of necrosis in the plants were studied after 30,45 and 60 days. Selected shoot tips removed from the plants contaminated with $F$. subglutinans were inoculated to check their viability as pathogen-free clones. The results revealed the influence of the cultivation media in the regeneration of plants and the viability of clonal cleansing of infected plants. It was also noted that $100 \%$ of the regenerated plants remained pathogen-free.

Key words: Ananas comosus, pineapple, culture medium, shoot tip
\end{abstract}

\section{INTRODUÇÃO}

Os cultivares de abacaxi (Ananas comosus L. Merr) atualmente mais cultivados no Brasil, Pérola e Smooth Cayene, apresentam alta susceptibilidade à fusariose (Ventura, 1994), considerada a doença de maior importância para a cultura no país. A fusariose, causada pelo Fusarium subglutinans, caracteriza-se pela exudação de uma substância gomosa que, além de provocar a podridão do fruto infecta as mudas que são as unidades propagativas nesta cultura. A estimativa de perdas situase em $30 \%$ para os frutos e cerca de $20 \%$ para as mudas. Atualmente a doença ocorre praticamente em todas as regiões produtoras do Brasil (Ventura, 1994).

As enfermidades que acometem o sistema vascular das plantas são difíceis de combater por meio de produtos químicos (Pierick, 1990). Por outro lado, o cultivo de meristemas, além de ser o explante mais indicado na multiplicação clonal in vitro permite a obtenção de clones sadios a partir de plantas infectadas (Grattapaglia \& Machado, 1997).

Algumas hipóteses tentam esclarecer o motivo pelo qual nem todas as células de uma planta encontramse infectadas. Acredita-se que a maior atividade de síntese proteica no tecido meristemático desfavoreceria a multiplicação do patógeno e a incipiente ligação vascular do meristema com o restante dos tecidos, proporcionaria uma menor distribuição das partículas patogênicas (Grattapaglia \& Machado, 1990).

A eliminação de vírus já foi registrada para amendoim (Morris et al., 1997), morango (Collin \& Edwards, 1998) e batata-doce (Gama, 1988). No que se refere à eliminação de fungos, também já foram alcançados resultados positivos com cravo e gladíolo, infectados por F. roseum e F. oxysporum, respectivamente (Pierik, 1990). 
A percentagem de regeneração de plantas a partir de meristemas ou ápices caulinares é baixa para algumas espécies vegetais. Vários fatores são apontados como responsáveis, destacando-se a composição do meio nutritivo e a concentração e combinação de reguladores de crescimento (Pierik, 1990; Grattapaglia \& Machado, 1997). Outros fatores como intensidade de $\mathrm{O}_{2}$ e $\mathrm{CO}_{2}$, luminosidade, temperatura, também podem interferir na regeneração de plantas.

As citocininas são importantes para o cultivo de ápices caulinares sendo a 6-benzilaminopurina (BAP) a que tem proporcionado melhores resultados (Hu \& Wang, 1983; Grattapaglia \& Machado, 1997). Auxinas e giberelinas são empregadas com menor frequência e em menores concentrações do que as citocininas (Smith \& Murashige, 1970). Entre as auxinas, o ácido 3-indolacético (AIA) é o mais recomendado ao cultivo de meristemas (Grattapaglia \& Machado, 1997) e, dentre as giberelinas, o ácido giberélico $\left(\mathrm{GA}_{3}\right)$ além de favorecer o alongamento da parte aérea, é capaz de reduzir a percentagem de explantes necrosados (Valles \& Boxus, 1987).

Além do meio empregado e das condições de desenvolvimento e crescimento, os resultados do cultivo in vitro de ápices caulinares sofrem uma marcada influência do genótipo. Assim, resultados diferentes são observados tanto no cultivo de diferentes espécies, como no de diferentes variedades de uma mesma espécie (Castro \& Andrade, 1995).

Devido a perdas consideráveis na produção de frutos de abacaxi e considerando-se a ausência de trabalhos com regeneração e recuperação de plantas de abacaxizeiro livres de fungos, o presente trabalho teve como objetivo adequar um protocolo para o cultivo in vitro de ápices caulinares de abacaxizeiro, visando viabilizar a limpeza clonal de plantas infectadas por $F$. subglutinans.

\section{MATERIAL E MÉTODOS}

\section{EXPERIMENTO I - Meios nutritivos}

Mudas sadias do tipo coroa de abacaxizeiro cv. Pérola, provenientes do município de Pombos - PE, foram trazidas ao laboratório para retirada do ápice caulinar. Inicialmente, as mudas foram lavadas com água corrente e detergente comercial. Em seguida, as folhas e raízes foram retiradas e o restante dos tecidos permaneceu em uma solução $\left(2,0 \mathrm{~g} \mathrm{~L}^{-1}\right)$ do fungicida Methyl [1[(butylamino) carbonyl] - $1 \mathrm{H}$ - benzimidazol - $2-\mathrm{YL}$ ] carbamate (Benomyl), durante 10 minutos. Após enxágüe com água destilada, para eliminação do excesso de Benomyl, o ápice caulinar e tecidos adjacentes, medindo aproximadamente $50 \mathrm{~mm}$, foi isolado e desinfestado em câmara de fluxo laminar. A desinfestação fez-se submergindo o explante em álcool $70 \%$ por 1 minuto, seguindo-se de imersão em hipoclorito de sódio a 2,5\%, por 2 minutos. $O$ excesso de hipoclorito foi eliminado submetendo o explante a três lavagens com água deionizada estéril. $O$ ápice caulinar, com aproximadamente $1,0 \mathrm{~mm}$, foi retirado com auxílio de lupa e inoculado em tubo de ensaio $(15,0 \times 2,5 \mathrm{~cm})$, contendo $10 \mathrm{~mL}$ de meio de cultivo. Os tubos, devidamente fechados com papel alumínio e selados com plast film (filme de PVC transparente), foram mantidos por 60 dias em sala de crescimento a uma temperatura de $25^{\circ} \mathrm{C}^{+} 2$ e fotoperíodo de $16 \mathrm{~h}$. Foram estabelecidos nove tratamentos (TABELA 1) que consistiram de diferentes meios básicos líquidos combinados ou não, com reguladores de crescimento. Foram testados os meios básicos MS (Murashige \& Skoog, 1962); $B_{5}$ (Gamborg et al., 1968) e $N_{6}$ (Chu et al., 1975) com as respectivas vitaminas, além do meio MS com metade da concentração salina. Esses meios foram suplementados ou não com 1,4 $\mu \mathrm{M}$ de $\mathrm{GA}_{3}$ e $2,8 \mu \mathrm{M}$ de AIA. Utilizou-se também, como tratamento controle, o meio de multiplicação para abacaxizeiro, que consiste do meio MS básico com 8,8 $\mu$ M de BAP (Ventura, 1994).

A unidade experimental consistiu de um tubo de ensaio contendo um ápice caulinar. Cada um dos nove tratamentos foi repetido em 5 tubos de ensaio. As avaliações se deram aos 30, 45 e 60 dias após a inoculação dos ápices caulinares, através da contagem do número de explantes necrosados. As análises estatísticas foram realizadas aplicando-se o teste de qui-quadado $\left(\chi^{2}\right)$ para testar a homogeneidade das proporções de explantes necrosados nos 9 meios de cultivo e nas três épocas de avaliação.

\section{EXPERIMENTO II - Limpeza clonal}

Cinquenta mudas do tipo coroa de abacaxizeiro cv. Pérola, com sintomas de fusariose, provenientes do município de Pombos - PE, foram trazidas ao laboratório para retirada do ápice caulinar. Todo o processo de excisão e desinfestação dos explantes foi idêntico ao citado no experimento I. Os ápices caulinares foram inoculados sobre ponte de papel nos meios de cultivo previamente selecionados no experimento I (25 ápices inoculados no meio $\mathrm{N}_{6}$ com $\mathrm{GA}_{3}$ e AIA e 25 no MS com BAP).

TABELA 1 - Meios nutritivos testados para regeneração de ápices caulinares de abacaxizeiro.

\section{TRATAMENTOS}

MS $\left(1,4 \mu \mathrm{M}\right.$ de $\mathrm{GA}_{3}+2,8 \mu \mathrm{M}$ de AIA $)$

$\mathrm{N}_{6}\left(1,4 \mu \mathrm{M}\right.$ de $\mathrm{GA}_{3}+2,8 \mu \mathrm{M}$ de AIA $)$

$\mathrm{B}_{5}\left(1,4 \mu \mathrm{M}\right.$ de $\mathrm{GA}_{3}+2,8 \mu \mathrm{M}$ de $\left.\mathrm{AlA}\right)$

$1 / 2 \mathrm{MS}\left(1,4 \mu \mathrm{M}\right.$ de $\mathrm{GA}_{3}+2,8 \mu \mathrm{M}$ de $\left.\mathrm{AlA}\right)$

MS $(8,8 \mu \mathrm{M}$ de BAP $)$

MS

$\mathrm{N}_{6}$

$\mathrm{B}_{5}$

$1 / 2$ MS 
As observações quanto ao desenvolvimento dos ápices caulinares foram realizadas diariamente. Aproximadamente dois meses depois, quando os propágulos começaram a emergir, foram transferidos para o meio de regeneração (MS líquido, sem fitorreguladores), utilizando-se algodão como suporte. Após a expansão foliar das plantas (aproximadamente 60 dias), realizou-se o teste de indexação. Para o referido teste foram coletados segmentos foliares de aproximadamente $1,0 \mathrm{~cm}^{2}$, de plantas provenientes do cultivo in vitro dos ápices caulinares de plantas com fusariose. Os segmentos de folha foram inoculados em placa de Petri $(10,0 \mathrm{~cm}$ de diâmetro), contendo meio BDA (batata-dextrose-ágar), os quais permaneceram no laboratório a uma tempe- ratura de $25^{\circ} \mathrm{C}$ e luminosidade ambiente. Cinco dias após a inoculação, o material vegetal foi avaliado quanto ao desenvolvimento do fungo fitopatogênico $F$. subglutinans.

\section{RESULTADOS E DISCUSSÃO}

\section{EXPERIMENTO I - Meios nutritivos}

Mediante a análise estatística dos dados pelo teste qui-quadrado $\left(\chi^{2}\right)$, constatou-se que os percentuais gerais de necrose dos ápices caulinares do abacaxizeiro foram 48,9, 64,4 e 66,7\% aos 30, 45 e 60 dias após a inoculação, respectivamente. O período de cultivo não teve efeito sobre o percentual de meristemas necrosados, conforme o resultado não significativo do teste de $\chi^{2}$. Porém, comparando-se as proporções de ápices caulinares necrosados nos nove meios testados, também através do teste $\chi^{2}$, os resultados indicaram heterogeneidade entre as proporções de necrose causadas pelo uso de diferentes meios. Dos meios testados, apenas o $\mathrm{N}_{6}$ suplementado com $\mathrm{GA}_{3}$ e AIA e o MS suplementado com BAP, apresentaram maior proporção de ápices não necrosados, nas três épocas de avaliação. Não observouse necrose no total de ápices inoculados no meio $\mathrm{N}_{6} \mathrm{com}$ $\mathrm{GA}_{3}$ e AIA durante todo o período de observação, ao passo que no meio MS suplementado com BAP, $20 \%$ dos ápices necrosaram (TABELA 2). O baixo percentual de necrose deveu-se, provavelmente, à adição de $8,8 \mu \mathrm{M}$ de BAP ao meio MS, uma vez que a adição de citocininas ao meio é considerada essencial para estímulo inicial do desenvolvimento dos ápices caulinares (Quak, 1988). Dentre as citocininas o BAP é considerada a mais eficiente para a proliferação de parte aérea (Grattapaglia \& Machado,1990). A utilização de BAP em concentrações variáveis na faixa de 0,89 a 9,98 $\mu \mathrm{M}$ permitiram a Kartha et al. (1977), a regeneração de grande número de plantas de tomate a partir de meristema apical.

Os bons resultados obtidos com $\mathrm{N}_{6}$ com AIA e $\mathrm{GA}_{3}(100 \%$ de ápices caulinares não necrosados)(TABELA 2), concordam com Morel et al. (1968), citado por Bhojwani \& Razdan (1983) que reportaram o favorecimento do crescimento e diferenciação dos propágulos de dália na presença de pequenas concentrações de $\mathrm{GA}_{3}$. Esses
TABELA 2 - Percentagem de necrose dos ápices caulinares de abacaxizeiro, cv. Pérola, após 30, 45 e 60 dias de inoculação, a $25^{\circ} \mathrm{C}+2$ e fotoperíodo de $16 \mathrm{~h}$ em diferentes meios de cultura.

\begin{tabular}{|c|c|c|c|}
\hline \multirow{3}{*}{ Tratamentos } & \multicolumn{3}{|c|}{ Dias de cultivo } \\
\hline & 30 & 45 & 60 \\
\hline & \multicolumn{3}{|c|}{----- \% ------ } \\
\hline $\mathrm{MS}\left(1,4 \mu \mathrm{M}\right.$ de $\mathrm{GA}_{3}+2,8 \mu \mathrm{M}$ de AlA $)$ & 80 & 80 & 80 \\
\hline $\mathrm{N}_{6}\left(1,4 \mu \mathrm{M}\right.$ de $\mathrm{GA}_{3}+2,8 \mu \mathrm{M}$ de $\left.\mathrm{AlA}\right)$ & 0 & 0 & 0 \\
\hline $\mathrm{B}_{5}\left(1,4 \mu \mathrm{M}\right.$ de $\mathrm{GA}_{3}+2,8 \mu \mathrm{M}$ de $\left.\mathrm{AlA}\right)$ & 40 & 60 & 80 \\
\hline $1 / 2 \mathrm{MS}\left(1,4 \mu \mathrm{M}\right.$ de $\mathrm{GA}_{3}+2,8 \mu \mathrm{M}$ de $\left.\mathrm{AlA}\right)$ & 20 & 60 & 60 \\
\hline MS $(8,8 \mu \mathrm{M}$ de BAP $)$ & 0 & 20 & 20 \\
\hline MS & 80 & 100 & 100 \\
\hline$N_{6}$ & 60 & 60 & 60 \\
\hline $\mathrm{B}_{5}$ & 80 & 100 & 100 \\
\hline $1 / 2 \mathrm{MS}$ & 80 & 100 & 100 \\
\hline
\end{tabular}

autores verificaram também que $\circ \mathrm{GA}_{3}$ em combinações com BAP e ANA, foi essencial para a regeneração de plântulas de mandioca a partir de ápices caulinares. Há registros de que a adição de $\mathrm{GA}_{3}$ ao meio de cultura estimula sensivelmente o desenvolvimento de meristema de tomateiro e que baixas concentrações dessa giberelina $(1,4 \mu \mathrm{M})$, favorecem o crescimento de brotos (Novák \& Masková, 1979).

O período de cultivo não teve efeito sobre o percentual de meristemas necrosados. Por outro lado, observou-se que em todos os meios desprovidos de reguladores de crescimento a frequência de necrose foi em média $90 \%$, alcançando a totalidade na maioria deles (TABELA 2). Segundo Smith \& Murashige (1970) o domo meristemático de um ápice caulinar não é autônomo no que diz respeito ao suprimento de auxina. A adição de fitorreguladores provavelmente supre deficiências hormonais nos explantes inoculados (Grattapaglia \& Machado, 1990).

Observou-se que os diferentes meios basais com uma mesma dosagem de reguladores induziram respostas diferenciadas em um mesmo tipo de explante de um mesmo cultivar, como foi o caso dos ápices caulinares cultivados nos meios $\mathrm{N}_{6}$ e MS com $\mathrm{GA}_{3}$ e AIA, evidenciando a importância dos demais componentes do meio de cultura.

Após a avaliação dos meios de cultivo testados, foram selecionados como mais eficientes os meios $\mathrm{N}_{6}$, com $\mathrm{GA}_{3}$ e AIA, e o meio MS com BAP. Os ápices caulinares cultivados nesses meios, mostraram-se mais vigorosos e promissores à regeneração de plantas.

\section{EXPERIMENTO II - Limpeza clonal}

Dos 25 ápices caulinares cultivados no meio $\mathrm{N}_{6}$, com $\mathrm{GA}_{3}$ e AIA, 13 apresentaram folhas emergentes $\mathrm{e}$ foram transferidos para meio de regeneração, sem fitorreguladores. Neste meio, 4 regeneraram plantas, o que representou $16 \%$ do total de ápices inicialmente inoculados. 
Dos outros 25 ápices caulinares cultivados em meio MS com BAP, 12 foram transferidos para o meio de regeneração, onde 8 explantes regeneraram plantas, correspondendo a $32 \%$ dos ápices inicialmente inoculados (Figura 1).

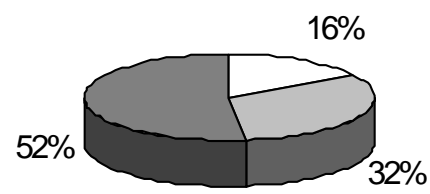

\section{$\square \mathrm{N} 6(\mathrm{GA3}$ e AIA) $\square \mathrm{MS}(\mathrm{BAP})$ $\square$ Não regenerados}

Figura 1 - Percentual de regeneração, aos 60 dias de cultivo em meio MS, de ápices caulinares de abacaxizeiro, cv. Pérola, provenientes do cultivo in vitro nos meios nutritivos $\mathrm{N}_{6}\left(1,4 \mu \mathrm{M}\right.$ de $\mathrm{GA}_{3}+2,8 \mu \mathrm{M}$ de AIA) e $\mathrm{MS}$ $(8,8 \mu \mathrm{M}$ de BAP $)$.

$O$ teste de qui-quadrado $\left(\chi^{2}\right)$, não evidenciou diferenças significativas entre as proporções de ápices desenvolvidos nos dois meios de cultivo originais nem entre as proporções de plantas regeneradas $\left(\chi^{2}=0,053\right.$, não significativo para ápices desenvolvidos e $\chi^{2}=1,75$, não significativo para plantas regeneradas). Segundo Pierik (1987), a percentagem de plantas obtidas mediante a cultura de ápices caulinares é geralmente baixa devido a fatores como infecção, ressecamento, oxidação, meio nutritivo inadequado, além do fenômeno da dormência. Baptista et al. (1993), trabalhando com videira, conseguiram a regeneração de até $35 \%$ dos meristemas em meio suplementado com 4,4 $\mu \mathrm{M}$ de BAP. Esse percentual, similar aos obtidos com os ápices caulinares de abacaxizeiro, é considerado favorável por muitos autores em vista da dificuldade da regeneração dos meristemas.

Para eliminação de microrganismos presentes no sistema vascular, quanto menor o explante isolado ou quanto mais distante estiver das regiões subjacentes vascularizadas, maior a chance de êxito na obtenção de plantas sadias. Porém, explantes muito pequenos não chegam a desenvolver-se ou o fazem muito lentamente (Grattapaglia \& Machado, 1997). No presente experimento, no qual os ápices caulinares de abacaxizeiro foram inoculados com $1,0 \mathrm{~mm}$, constatou-se que $100 \%$ das plantas regeneradas estavam livres de patógenos, conforme detectado pelo teste de indexação. O tempo de regeneração das plantas, após a inoculação do ápice, foi de aproximadamente 120 dias. Estas, por sua vez, ao serem transferidas para o meio de multiplicação produziram, em média, três novos brotos a cada 30 dias. Os resultados indicam a viabilidade da técnica para limpeza clonal de abacaxizeiro afetado pela fusariose, para produção de mudas sadias.

\section{CONCLUSÕES}

- Os meios $\mathrm{N}_{6}$ suplementado com AIA e $\mathrm{GA}_{3}$ e MS com BAP, foram os mais indicados para regeneração de ápices caulinares de abacaxizeiro.

- O cultivo de ápices caulinares, permitiu a limpeza clonal de abacaxizeiro infectado por $F$. subglutinans.

\section{REFERÊNCIAS BIBLIOGRÁFICAS}

BAPTISTA, C.R.; KUNIYUKI, H.; MULLER, G.W.; BETTI, J.A. Obtenção de clones livres de vírus de sete variedades de videira através da cultura de meristema em São Paulo. Summa Phytopathologica, v.19, p.96-98, 1993.

BHOJWANI, S.S.; RAZDAN, M.K. Production of pathogen free plants In: REINERT J.(Ed.) Plant tissue culture: theory and practice. Amsterdan: Elsevier, 1983. p.287-312.

CASTRO, A.O.A.; ANDRADE, A.G. Cultura in vitro de meristemas de batata-doce (Ipomoea batatas (L.) Lam) Pesquisa Agropecuária Brasileira, v.30, p.917-922, 1995.

COLLIN, H.A.; EDWARDS, S. Plant cell culture. New York: Springer-Verlag, 1998. 158p.

CHU, C.C.; WANG, C.C.; SUN, C.S.; HSU, C.; YIN, K.C.; CHU, C.Y.; BI, F.Y. Establishment of an efficient mediun for anther culture of rice, through comparative experiments on the nitrogen sources. Scientia Sinnica, v.18, p.659-668, 1975.

GAMA, M.I.C.S. Produção de plantas de batata-doce livres de vírus por termoterapia e cultura de meristemas. Fitopatologia Brasileira, v.13, p.283-286, 1988.

GAMBORG, O.L.; MILLER, R.A.; OJIMA, K. Nutrient requirements of suspension cultures of soybean root cells. Experimental Cell Research, v.50, p.151-158, 1968.

GRATTAPAGLIA, D.; MACHADO, M.A. Micropropagação. In: TORRES, A.; CALDAS, L.S. (Ed.) Técnicas e aplicações de cultura de tecidos de plantas. Brasília: EMBRAPA, CNPH, 1990. p.99-169.

GRATTAPAGLIA, D.; MACHADO, M.A. Micropropagação. In: CURSO SISTEMAS DE MICROPROPAGAÇÃO DE PLANTAS, Brasília, 1997. Anais Brasília: EMBRAPA, CNPH, 1997 p.71115.

HU, C.Y.; WANG, P.J. Meristem, shoot tip and bud culture. In: EVANS, D.A.; SHARP, W.R.; AMMIRATO, P.V.; YAMADA, Y. (Ed.) Handbook of plant cell culture. New York: MacMillan, 1983. p.117-227.

KARTHA, K.K.; CHAMPOUX, S.; GAMBORG, O.L.; PAHL, K. In vitro propagation of tomato by shoot apical meristem culture. Hortscience, v.3, p.346-349, 1977.

MORRIS, J.B.; DUNN, S.; PINNOW, D.L.; HOPKING, M.S.; PITTMAN, R.N. Meristem culture for virus elimination and peanut interspecific hybrid preservation. Crop Science, v.37, p.591-594, 1997.

MURASHIGE, T.; SKOOG, F. A revised medium for rapid growth and bio assays with tobacco tissue cultures. Physiologia Plantarum, v.15, p.473-497, 1962.

NOVÁK, F.J.; MASKOVÁ, I. Apical shoot tip culture of tomato. Science Horticulturae, v.10, p.337-344, 1979.

PIERIK, R.L.M. In vitro culture of higher plants. Boston: Martinus Nijhoff, 1987. 344p.

PIERIK, R.L.M. Produccion de plantas libres de enfermedades In: PIERIK, R.L.M. (Ed.) Cultivo in vitro de las plantas superiores. Madrid: Ediciones Mundi-Pronsa, 1990. p.169-180.

QUAK, F. Meristem culture and virus-free plants. In: REINERT, J.; BAJAJ, Y.P.S. (Ed.) Applied and fundamental aspects of plant cell, tissue and organ culture. New Dalhi: Narosa Publishing House, 1988. p.599-615.

SMITH, R.; MURASHIGE, T. In vitro development of the isolate shoot apical meristem of angiosperms. Americam Journal of Botany, v.57, p.562-569, 1970.

VALLES, M.; BOXUS, P. Micropropagation of several Rosa hybrida L. cultivars. Acta Horticulturae, v.10, p.337-344, 1987.

VENTURA, J.A. Fusariose do abacaxizeiro: caracterização do patógeno, epidemiologia da doença, resistência e micropropagação do hospedeiro in vitro. Viçosa, 1994. 111p. Tese (Doutorado) - Universidade Federal de Viçosa.

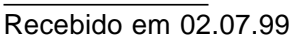

